\title{
Erratum to: Impact of Inhalation Flow, Inhalation Volume and Critical Handling Errors on Delivered Budesonide/Formoterol Dose in Different Inhalers: An In Vitro Study
}

Christer Janson · Thomas Lööf · Gunilla Telg $\cdot$ Georgios Stratelis

Published online: April 26, 2017

(C) Springer Healthcare 2017. This article is an open access publication

Erratum to: Pulm Ther

DOI 10.1007/s41030-017-0042-6

The authors of the above-mentioned paper have noticed an error in their paper subsequent to publication and would like to make the following correction.

The heading 'RESULTS' is missing following the 'Compliance with Ethics Guidelines' section and should be added.

The original publication has been updated to reflect this.
The online version of the original article can be found under doi:10.1007/s41030-017-0042-6.

C. Janson $(\varangle) \cdot$ G. Stratelis

Department of Medical Sciences, Respiratory,

Allergy and Sleep Research, Uppsala, Sweden

e-mail: christer.janson@medsci.uu.se

T. Lööf

AstraZeneca R\&D, Mölndal, Sweden

G. Telg · G. Stratelis

AstraZeneca Nordic-Baltic, Södertälje, Sweden
Open Access. This article is distributed under the terms of the Creative Commons AttributionNonCommercial 4.0 International License (http://creativecommons.org/licenses/by-nc/4. $0 /$ ), which permits any noncommercial use, distribution, and reproduction in any medium, provided you give appropriate credit to the original author(s) and the source, provide a link to the Creative Commons license, and indicate if changes were made. 